\title{
LAJU PERTUMBUHAN SPESIFIK Diaphanosoma sp. DENGAN PAKAN Chaetoceros sp., Nannochloropsis sp., Porphyridium sp., DAN Tetraselmis sp.
}

\section{The Growth Rate Spesific Diaphanosoma sp. With Feed Chaetoceros sp., Nannochloropsis sp., Porphyridium sp., And Tetraselmis sp.}

\author{
Nurmalasari $^{1}$, Emy Rusyani ${ }^{2}$, Ika Chandra ${ }^{2}$, Syaeful Anwar ${ }^{3}$, dan Reno Fitriyanti ${ }^{4}$ \\ ${ }^{1}$ Program Studi Ilmu Perikanan, Fakultas Perikanan Universitas PGRI Palembang \\ ${ }^{2}$ Koodinator Laboratorium Zooplankton Balai Besar Perikanan Budidaya Laut Lampung \\ ${ }^{3}$ Program Studi Budidaya Ikan Fakultas Perikanan Universitas PGRI Palembang \\ ${ }^{4}$ Program Studi Teknik Kimia Fakultas Teknik Universitas PGRI Palembang \\ * Corresponding author : syaeful.anwar81@gmail.com
}

\begin{abstract}
ABSTRAK
Diaphanosoma sp. merupakan salah satu spesies dari Cladocera yang dapat diberikan pada larva ikan dimana memiliki keunggulan diantaranya yaitu mudah dikultur dengan pertumbuhan yang singkat sehingga dapat diproduksi secara massal. Diaphanosoma sp. digunakan sebagai pakan alami larva ikan, permasalahannya adalah kebutuhan masih kurang terpenuhi jika hanya dari alam. Maka dari itu dibutuhkan budidaya Diaphanosoma sp. Penelitian ini bertujuan untuk menghitung laju pertumbuhan spesifik Diaphanosoma sp. dengan pakan fitoplankton berbeda. Penelitian ini dilakukan pada bulan Maret-April 2019 di Laboratorium Zooplankton Balai Besar Perikanan Budidaya Laut (BBPBL) Lampung. Metode yang digunakan adalah eksperimen laboratorium dengan Rancangan Acak Lengkap (RAL) menggunakan 4 taraf perlakuan dengan 3 ulangan. Perlakuan (P) yang dilakukan adalah pemberian pakan Diaphanosoma sp. menggunakan fitoplankton berbeda dengan P1 (Chaetoceros sp.), P2 (Nannochloropsis sp.), P3 (Porphyridium sp.), dan P4 (Tetraselmis sp.). Data yang diperoleh kemudian dianalisa menggunakan one way ANOVA. Hasil penelitian menunjukkan bahwa perlakuan terbaik terhadap Diaphanosoma sp. terdapat pada P3 dengan laju pertumbuhan spesifik (7.64\%).
\end{abstract}

Kata kunci : Diaphanosoma sp., Fitoplankton, Pertumbuhan.

\begin{abstract}
Diaphanosoma sp. is one of the species of Cladocera it can be given to fish larvae which has the advantage of being easily cultured with short growth, so that it can be mass produced. Diaphanosoma sp. used as natural food for fish larvae, the problem is Diaphanosoma sp. need was not enough if it is only from the nature. So it is needed to cultivate the Diaphanosoma sp. The purpose of this study is to calculate growth rate spesific Diaphanosoma sp. with different phytoplankton feeds. This study was conducted on MarchApril 2019 at the Zooplankton Laboratory, Center for Maritime Aquaculture (BBPBL) Lampung. The method of used this study laboratory experiment with a completely randomized design (RAL) using 4 treatments with 3 replications. The treatment $(\mathrm{P})$ was taken by feeding of Diaphanosoma sp. with different phytoplankton with P1 (Chaetoceros sp.), P2 (Nannochloropsis sp.), P3 (Porphyridium sp.), and P4 (Tetraselmis sp.). The data
\end{abstract}


was analyzed using one way ANOVA. The results showed the best treatment was P3 with growth rate spesific $7.64 \%$.

Keywords: Diaphanosoma sp., Phytoplankton, Growth.

\section{PENDAHULUAN}

Pengembangan usaha perikanan budidaya sangat tergantung pada ketersediaan induk unggul dan benih berkualitas serta ketersedian pakan. Potensi sumberdaya perikanan budidaya cukup besar dengan aneka jenis ikan dan biota air yang bernilai ekonomis memungkinkan untuk dibudidayakan (KKP, 2011). Pakan merupakan kunci keberhasilan dalam budidaya perikanan, karena berpengaruh terhadap ketahanan dan perkembangan larva. Jenis pakan yang dapat diberikan pada ikan ada dua jenis, yaitu pakan alami dan pakan buatan. Salah satu faktor terpenting dalam keberhasilan budidaya ikan adalah penggunaan pakan alami. seperti fitoplankton dan zooplankton (Tavares dan Pereira, 2008).

Menurut Basri (2013), pakan alami mempunyai kandungan gizi yang lengkap, mudah dicerna dalam saluran pencernaan, tidak menyebabkan penurunan kualitas air dan dapat meningkatkan daya tahan benih ikan terhadap penyakit maupun perubahan kualitas air dan ukuran dari pakan alami yang diperlukan untuk benih ikan harus lebih kecil dari ukuran lebar mulutnya. Salah satu pakan alami yang banyak digunakan untuk pembenihan adalah ordo Cladocera, yang termasuk golongan ini adalah Moina sp, Daphnia sp., Penilia, Ceriopdaphnia, Podon, Evadne dan Diaphanosoma sp. (Asriyana dan Yuliana, 2012). Hal ini didasari penelitian Maryam, et al. (2015) meneliti mengenai pengaruh perbedaan fitoplankton Tetraselmis sp., Porphyridium sp., dan Chaetoceros sp. terhadap laju pertumbuhan Diaphanosoma sp Tujuan penelitian ini yaitu. Untuk menghitung laju pertumbuhan spesifik tertinggi Diaphanosoma sp. yang diberi pakan fitoplankton Chaetoceros sp., Nannochloropsis sp., Porphyridium sp., dan Tetraselmis sp.

\section{METODE PENELITIAN}

Penelitian ini telah dilaksanakan pada tanggal 1 Maret sampai 4 April 2019. Di Laboratorium Zooplankton Balai Besar Perikanan Budidaya Laut (BBPBL) Lampung yang berlokasi di JL.Yos Sudarso, Desa Hanura, Kecamatan Teluk Pandan Kabupaten Pesawaran, Provinsi Lampung.

Metode penelitian ini menggunakan metode eksperimen laboratorium (percobaan) dengan menggunakan Rancangan Acak Lengkap (RAL) dengan menggunakan 4 perlakuan dan 3 kali ulangan. Parameter yang diamati dalam penelitian ini adalah sebagai berikut :

\section{Laju Pertumbuhan Spesifik}

Menurut Becker (1994) laju pertumbuhan spesifik Diaphanosoma sp. Dihitung menggunakan rumus sebagai berikut:

$\mu=\frac{\operatorname{Ln} N_{t-} \operatorname{Ln} N_{0}}{t} \times 100 \%$

Keterangan:

$\mu \quad=$ Laju pertumbuhan spesifik (\%/ hari)

$\mathbf{N}_{\mathbf{0}}=$ Kepadatan awal populasi (Ind/L)

$\mathbf{N}_{\mathbf{t}}$ =Kepadatan akhir populasi fase eksponensial (Ind/L)

t $=$ Waktu (hari) dari $\mathrm{N}_{0}$ ke $\mathrm{N}_{\mathrm{t}}$ 
HASIL DAN PEMBAHASAN

\section{Laju Pertumbuhan Spesifik}

Untuk dapat mengetahui Laju Pertumbuhan Spesifik Diaphanosoma sp. dalam masing-masing perlakuan dapat dilihat pada Gambar 1.

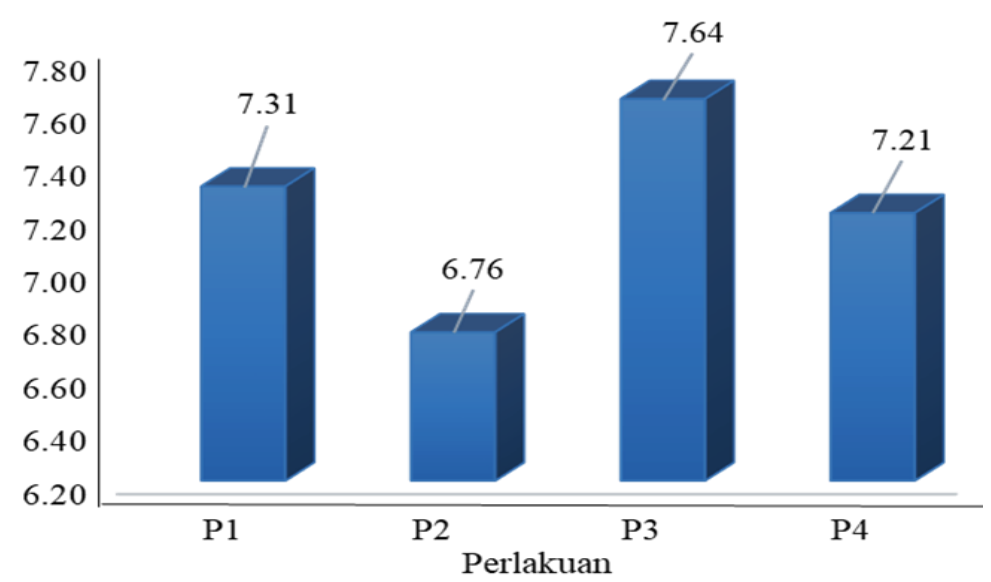

Gambar 1. Rata-rata Laju Pertumbuhan Spesifik Diaphanosoma sp.

Berdasarkan Gambar 1 diatas, maka laju pertumbuhan spesifik Diaphanosoma sp. tertinggi pada perlakuan P3 sebesar 7.64\%, kemudian diikuti perlakuan P1 sebesar $7.31 \%$, selanjutnya perlakuan P4 sebesar $7.21 \%$, dan laju pertumbuhan spesifik terendah pada perlakuan $\mathrm{P} 2$ sebesar $6.76 \%$.

Tingginya laju pertumbuhan Diaphanosoma sp. pada perlakuan P3 diduga karena pengaruh dari perbedaan fase pertumbuhan fitoplankton dalam media kultur Diaphanosoma sp. yaitu fase eksponensial. Pada fase ini sel-sel telah mengalami perkembangan dengan baik sehingga pertumbuhannya cepat dan konstan. Hal ini sesuai dengan pendapat Isnansetyo dan Kurniastuty (1995) dalam Wina (2013) menyatakan bahwa pada fase eksponensial diawali dengan pembelahan sel dengan laju pertumbuhan konstan, pada kondisi kultur yang optimum, laju pertumbuhan pada fase ini mencapai maksimal. Sedangkan pada perlakuan P2 yaitu dengan pemberian pakan Nannochloropsis sp. menghasilkan laju pertumbuhan spesifik paling rendah dibandingkan perlakuan-perlakuan yang lain.
Hal ini diduga karena kandungan gizi pada fitoplankton Nannochloropsis sp. mempunyai protein dan lemak yang cukup rendah. Kandungan nutrisi dari Nannochloropsis sp. adalah protein 38.65 $\%$, lemak $0.49 \%$ dan karbohidrat $0.048 \%$ dari berat kering (Isnansetyo dan Kurniastuty, 1995). Hal ini sesuai dengan pendapat Jhonson dkk (2006) menyatakan bahwa semua mikroorganisme seperti zooplankton sangat membutuhkan protein dan lemak.

Protein berfungsi sebagai untuk mempertahankan fungsi jaringan secara normal, perawatan jaringan tubuh dan petumbuhan, sedangkan asam lemak yang terkandung dalam lemak dibutuhkan oleh membran sel sebagai pembentuk jaringan telur.

Laju pertumbuhan spesifik tertinggi pada pemberian pakan Porphyridium sp. pada perlakuan P3 dibandingkan laju pertumbuhan spesifik Diaphanosoma sp. pada perlakuan P1, P2, dan P4. Hal ini diduga karena kandungan nutrisi pada perlakuan P3 lebih tinggi yaitu pada kandungan lemak dan protein dalam menunjang laju pertumbuhan dan perkembangan Diaphanosoma sp. 
Selain itu, ketersediaan pakan pada media pemeliharaan juga dimanfaatkan secara maksimum oleh Diaphanosoma sp. untuk pertumbuhannya. Hal ini sesuai dengan pendapat Novianty (2000) dalam Wina (2013) menyatakan bahwa pakan yang banyak mengandung lemak dan protein diberikan pada Crustaceae selain dirubah menjadi energi untuk pergerakan, keseimbangan dan metabolisme, juga digunakan untuk pertumbuhan dan perkembangan dari Diaphanosoma sp.

Untuk mengetahui pengaruh perlakuan berbeda pada pemberian pakan fitoplankton yang berbeda terhadap laju pertumbuhan spesifik dan waktu penggandaan Diaphanosoma sp. maka dilakukan uji statistik. Hasil perhitungan rata-rata masing-masing perlakuan dengan ulangan yang berbeda ditunjukkan pada Tabel 1.

Tabel 1. Analisis Sidik Ragam Laju Pertumbuhan Spesifik Diaphanosoma sp.

\begin{tabular}{|c|c|c|c|c|c|c|}
\hline \multirow{2}{*}{ SK } & \multirow{2}{*}{ DB } & \multirow{2}{*}{ JK } & \multirow{2}{*}{ KT } & \multirow{2}{*}{ F hitung } & \multicolumn{2}{|c|}{ F tabel } \\
\hline & & & & & $5 \%$ & $1 \%$ \\
\hline Perlakuan & 3 & 1.194 & 0.398 & 0.004 & 4.07 & 7.59 \\
\hline Galat & 8 & 713 & 89.125 & & & \\
\hline Total & 11 & 1.907 & & & & \\
\hline $\begin{array}{l}\text { eterangan : }{ }^{\text {tn }} \\
\mathrm{K}\end{array}$ & Berpe & ah Tidak & & & & \\
\hline
\end{tabular}

Pada Tabel 5. terlihat bahwa uji statistik untuk perlakuan berbeda pada pemberian pakan fitoplankton yang berbeda terhadap laju pertumbuhan spesifik Diaphanosoma sp. diketahui bahwa $\mathrm{F}_{\text {hitung }}<\mathrm{F}_{\text {tabel }}$ pada taraf 5\% $(0.004$ $<4.07)$ maupun $1 \%(0.004<7.59)$. Dapat dikatakan bahwa perbedaan perlakuan pemberian fitoplankton yang berbeda berpengaruh tidak nyata terhadap laju pertumbuhan spesifik Diaphanosoma sp. sehingga tidak diperlukan uji lanjut. Maka dari itu hipotesis dapat diambil kesimpulan bahwa $\mathrm{H}_{\mathrm{I}}$ ditolak dan $\mathrm{H}_{0}$ diterima. Karena nilai $\mathrm{F}_{\text {hitung }}<\mathrm{F}_{\text {tabel }}$ pada taraf $5 \%$ maupun $1 \%$.

\section{Kualitas Air Diaphanosoma sp.}

Hasil pengukuran kualitas air Diaphanosoma sp. selama penelitian dapat dilihat pada Tabel 2. berikut ini.

Tabel 2. Kualitas Air Diaphanosoma sp.

\begin{tabular}{lllll}
\hline \multirow{2}{*}{ Parameter } & \multicolumn{4}{c}{ Kisaran } \\
\cline { 2 - 5 } & \multicolumn{1}{c}{ PI } & \multicolumn{1}{c}{ P2 } & \multicolumn{1}{c}{ P3 } \\
\hline Suhu & $26-26.6$ & $26-26.6$ & $26-26.7$ & $26-26.7$ \\
pH & $81-83$ & $81-83$ & $81-83$ & $81-83$ \\
DO & $6.09-6.30$ & $7.06-5.85$ & $6.25-5.79$ & $6.03-6.07$ \\
Salinitas & $32-34$ & $32-35$ & $32-34$ & $32-34$ \\
Nitrit & $0.011-0.139$ & $0.017-0.103$ & $0.037-0.078$ & $0.240-0.211$ \\
Amoniak & $0.379-0.220$ & $0.368-0.297$ & $0.161-0.524$ & $0.312-0.907$ \\
\hline
\end{tabular}

Suhu

Secara fisiologis perbedaan suhu perairan sangat berpengaruh terhadap fekunditas, lama hidup, dan ukuran dewasa zooplankton. Secara ekologis perubahan suhu menyebabkan perbedaan komposisi dan kelimpahan zooplankton. 
Pada penelitian kultur Diaphanosoma sp. yang telah dilakukan selama 14 hari, dilakukan pengecekan suhu setiap hari sebanyak 3 (tiga) kali sehari selama penelitian berlangsung dan didapat angka 26-26.7 ${ }^{\circ} \mathrm{C}$ yang dapat dilihat pada tabel 2. Dengan angka tersebut maka suhu air pada kultur Diaphanosoma sp. berada pada kisaran optimal untuk kultur Diaphanosoma sp., dimana kisaran suhu optimal untuk kultur Diaphanosoma sp. berkisar antara 25-29.5 ${ }^{\circ} \mathrm{C}$ (Rusyani, dkk 2005).

$p H$

Dalam penelitian yang telah dilakukan selama 14 hari, dilakukan pengecekan $\mathrm{pH}$ setiap hari sebanyak 3 (tiga) kali sehari selama penelitian berlangsung. $\mathrm{pH}$ air pada kultur Diaphanosoma sp. selama penelitian didapat angka berkisar antara $8,1-8.3{ }^{\circ} \mathrm{C}$ yang dapat dilihat pada tabel 2. Dengan angka tersebut maka $\mathrm{pH}$ air pada kultur Diaphanosoma sp. berada pada kisaran optimal. Hal ini sesuai dengan pernyataan BBL (2007) bahwa kisaran pH yang ideal bagi kehidupan plankton antara 7.3-8.7.

\section{Oksigen Terlarut (DO)}

Pada penelitian selama 14 hari telah dilakukan pengecekan oksigen terlarut (DO) pada awal dan akhir penelitian. Pengecekan (DO) pada penelitian ini dilakukan di Laboratorium Penguji Kesehatan Ikan dan Lingkungan Balai Besar Perikanan Budidaya Laut (BBPBL) Lampung. Hasil pengukuran oksigen terlarut (DO) pada awal penelitian dari 4 perlakuan yaitu P1 U1 yaitu 6.09 ppm. Pada P2 U1 yaitu 7.06 ppm. Pada P3 U1 yaitu 6.25 ppm. Pada P4 U1 yaitu 6.03 ppm dan pada akhir penelitian P1 U1 yaitu 6.30 ppm. Pada P2 U1 yaitu 5.85 ppm. Pada P3 U1 yaitu 5.79 ppm. Pada P4 U1 yaitu $6.07 \mathrm{ppm}$ yang dapat dilihat pada tabel 2.
Dengan angka tersebut bisa
dikatakan jika oksigen terlarut (DO)
secara umum berada pada kisaran yang
optimal untuk kelangsungan hidup Diaphanosoma sp. Hal ini sesuai dengan pernyataan Sanusi (2004) menyatakan bahwa oksigen terlarut yang berkisar antara 5.45-7.00 ppm cukup baik bagi proses kehidupan plankton. Menurunnya kadar oksigen terlarut menjadi faktor penting untuk kehidupan Diaphanosoma sp.

$\begin{array}{ccr}\text { Menurunnya } & \text { kadar } & \text { oksigen } \\ \text { terlarut disebabkan } & \text { oleh } & \text { proses }\end{array}$ metabolisme dan organisme oleh organisme akuatik, atau dekomposisi oleh mikroba. Hal ini sesuai dengan pendapat Effendi (2003) dalam Susilowati (2014) menyatakan bahwa sumber utama oksigen dalam perairan adalah dari proses fotosintesis. Semakin subur suatu perairan akan semakin banyak zooplankton yang hidup di dalamnya dan akhirnya akan meningkatkan pasokan oksigen terlarut dalam air. Kandungan oksigen terlarut rendah disebabkan karena aktifitas respirasi yang lebih tinggi daripada fotosintesis.

\section{Amoniak}

Pada penelitian selama 14 hari telah dilakukan pengecekan amoniak pada awal dan akhir penelitian. Pengecekan amoniak dilakukan di Laboratorium Penguji Kesehatan Ikan dan Lingkungan Balai Besar Perikanan Budidaya Laut (BBPBL) Lampung. Untuk kadar amoniak pada awal penelitian dari 4 perlakuan yaitu P1 U1 yaitu $0.379 \mathrm{mg} /$ liter ppm. Pada P2 U1 yaitu $0.368 \mathrm{mg} / \mathrm{liter}$. Pada P3 U1 yaitu $0.161 \mathrm{mg} / \mathrm{liter}$. Pada P4 U1 yaitu $0.312 \mathrm{mg} /$ liter dan pada akhir penelitian P1 U1 yaitu $0,220 \mathrm{mg} / \mathrm{liter}$. Pada P2 U1 yaitu $0.297 \mathrm{mg} / \mathrm{liter}$. Pada P3 U1 yaitu $0.524 \mathrm{mg} /$ liter. Pada P4 U1 yaitu $0.907 \mathrm{mg} / \mathrm{liter}$ yang dapat dilihat pada tabel 2. 
Kadar amoniak dalam penelitian pada semua perlakuan pada awal dan akhir penelitian tidak sesuai dengan pendapat Boyd, (1982) menyatakan bahwa kadar amoniak $\left(\mathrm{NH}_{3}\right)$ dalam media pemeliharaan tidak boleh lebih dari 0.6 $\mathrm{mg} / \mathrm{l}$, karena dapat membahayakan organisme. Akan tetapi dengan kadar amoniak yang melampaui batas tersebut Diaphanosoma sp. masih dapat bertahan hidup dan berkembang biak hingga hari ke 14. Amoniak $\left(\mathrm{NH}_{3}\right)$ yang terkandung dalam suatu perairan merupakan salah satu hasil dari proses penguraian bahan organik (Aryanto, 2008).

\section{Salinitas}

Pada penelitian selama 14 hari telah dilakukan pengecekan salinitas pada awal dan akhir penelitian. Pengecekan salinitas dilakukan di Laboratorium Penguji Kesehatan Ikan dan Lingkungan Balai Besar Perikanan Budidaya Laut (BBPBL) Lampung. Untuk salinitas pada awal penelitian dari 4 perlakuan yaitu P1 U1 yaitu 32 ppt. Pada P2 U1 yaitu 32 ppt. Pada P3 U1 yaitu 32 ppt. Pada P4 U1 yaitu 32 ppt dan salinitas pada akhir penelitian P1 U1 yaitu 34 ppt. Pada P2 U1 yaitu 35 ppt. Pada P3 U1 yaitu 34 ppt. Pada perlakuan P4 U1 yaitu 34 ppt yang dapat dilihat pada tabel 2. Kadar salinitas dalam penelitian dikatakan normal, hal ini sesuai dengan Thariq, dkk (2007) menyatakan bahwa kisaran salinitas yang optimal untuk kehidupan plankton yaitu berkisar antara 25-35 ppt.

\section{Nitrit}

Nitrit merupakan bentuk peralihan antara amoniak dan nitrat, yang bersifat kurang stabil dan bersifat toksik terhadap organisme. Jika kondisi kondisi lingkungan maka mikroba nitrifikasi mampu mengoksidasi amonia dan nitrit menjadi nitrat. (Effendi, 2000). Pada penelitian ini pengukuran nitrit dilakukan dua kali selama penelitian yaitu pada awal dan akhir penelitian di Laboratorium Penguji Kesehatan Ikan dan Lingkungan Balai Besar Perikanan Budidaya Laut (BBPBL) Lampung.

Dimana pada awal penelitian media kultur Diaphanosoma sp. didapat kadar nitrit P1 U1 yaitu $0.011 \mathrm{mg} /$ liter. Pada P2 U1 yaitu 0.017 mg/l. Pada P3 U1 yaitu $0.037 \mathrm{mg} / \mathrm{l}$. Pada P4 U1 yaitu 0.240 $\mathrm{mg} / \mathrm{l}$ dan pada akhir penelitian P1 U1 yaitu $0.139 \mathrm{mg} / \mathrm{l}$. Pada P2 U1 yaitu 0,103 mg/liter. Pada P3 U1 yaitu $0.078 \mathrm{mg} / \mathrm{l}$. Pada P4 U1 yaitu $0,211 \mathrm{mg} /$ liter ${ }^{\circ} \mathrm{C}$ yang dapat dilihat pada tabel 2. Kadar nitrit dalam media kultur Diaphanosoma sp. pada awal penelitian pada perlakuan $\mathrm{P} 4$, dan pada akhir penelitian pada perlakuan P4 sangat tinggi dan tidak sesuai dengan pernyataan Buwono (2002) bahwa kadar nitrit normal untuk perairan adalah 0.7$0.15 \mathrm{mg} / \mathrm{l}$. akan tetapi dengan kadar nitrit yang tinggi tersebut Diaphanosoma sp. masih dapat bertahan hidup dan berkembang biak hingga hari ke 14 .

\section{SIMPULAN}

Laju pertumbuhan spesifik Diaphanosoma sp. tertinggi yaitu $7.64 \%$. Nilai $F_{\text {hitung }}<\mathrm{F}_{\text {tabel }}$ pada taraf $5 \%$ $(0.004<4.07)$ maupun $1 \%(0.004<7.59)$. perbedaan perlakuan pemberian fitoplankton yang berbeda berpengaruh tidak nyata, maka hipotesis yang diambil yaitu $\mathrm{H}_{1}$ ditolak dan $\mathrm{H}_{0}$ diterima.

\section{SARAN}

Berdasarkan hasil penelitian yang telah dilakukan diperoleh saran yang dapat dianjurkan dilakukan penelitian lanjutan mengenai jumlah kepadatan fitoplankton Pophyridium sp. yang berbeda untuk mengetahui kepadatan Pophyridium sp. yang optimal untuk laju pertumbuhan spesifik Diaphanosoma sp. 


\section{DAFTAR PUSTAKA}

Aryanto A. 2008. Laju Pertumbuhan Diaphanosoma sp. Dengan Pemberian Pakan Nannochloropsis sp. Tetraselmis sp. dan Dunaliella sp. Dalam Kondisi Laboratorium. Skripsi. Lampung: Universitas Lampung (tidak dipublikasikan).

Asriyana dan Yuliana. Produktivitas Perairan. Bumi Aksara, Jakarta.

Balai Besar Pengembangan Budidaya Laut. 2007. Budidaya Fitoplakton dan Zooplankton. Lampung: Direktorat Jenderal Perikanan Budidaya Departemen Kelautan dan Perikanan

Basri S. 2013. Pakan dan Pemberian Pakan. Kendari, Universitas Haluoleo.

Boyd, C.E, 1982. Water Quality Management For pond Fish Culture Development. In Aquaculture and Fish Science, Vol. 9. Elsevier Scientific Pub. Comp 318p.

Buwono, I. D.2002. Tambak Udang Windu Sistem Pengelolaan Berpola Intensif. Kanisisus. Yogyakarta.

Effendi, H. 2000. Telaah Kualitas Air : Bagi Pengelolaan Sumberdaya dan Lingkungan Perairan. Jurusan Manajemen Sumberdaya Perairan IPB. Bogor.

Effendi, H. 2003. Telaah Kualitas Air bagi Pengelolaan Sumber Daya dan Lingkungan Perairan. Kanisius. Yogyakarta. Indonesia.

Isnansetyo, A. dan Kurniastuty. 1995. Teknik Kultur Fitoplankton dan Zooplankton Pakan Alami untuk
Pembenihan Organisme Laut. Kanisius, Yogyakarta.

Jhonson. P.T ; J. Longcore And ER Preu. 2006. Chytrid infection of Daphnia Pulicarida : Development, ecology of polycaryum leave. Freswater biologi 51: 634-648.

Kementerian Kelautan Perikanan (KKP). 2011. Analisis Usaha Perikanan Budidaya. Jakarta: Kementerian Kelautan Perikanan.

Rusyani, E., L. Erawati. dan A Hermawan. 2005. Budidaya Zooplankton dalam Pembenihan Kuda Laut. Balai Budidaya Laut Lampung Dirjen Perikanan Budidaya DKP, Lampung.

Sanusi, H. 2004. Karakteristik Kimia Dan Kesuburan Perairan Teluk Pelabuhan Ratu Pada Musim Barat dan Timur. Jurnal Ilmu-ilmu Perairan dan Perikanan Indonesia. Jilid II, No 2. Departemen Sumber Daya Perairan, Fakultas Perikanan dan Ilmu Kelautan IPB Bogor. 89 hal.

Tavares, S.L.H and Pereira, A.M.L. 2008. Large Scale laboratory Cultures of Ankistrodesmus gracilis (Reisch) Korsikov (Chlorophyta) and Diaphanosoma biergei Korinek, 1981 (Cladocera). J. Biol., 68(4): 875883.

Thariq, M., V. Retno., S Antoro, dan L. Erawati. 2007. Biologi Fitoplankton dan Zooplankton dalam Budidaya Fitplankton dan Zooplankton. Balai Besar Pengembangan Budidaya Laut Lampung. Dirjen Perikanan Budidaya DKP, Lampung. 